DOI https://doi.org/10.18551/rjoas.2016-11.03

\title{
THE RUSSIAN POPULATION'S SOCIAL STATUS DEFINING ON THE RLMS-HSE POLLING
}

\author{
Sysoev N.A., Deputy Head \\ Department of Science Affairs, Monitoring and Statistical Office, \\ Plekhanov Russian University of Economics, Moscow, Russia \\ E-mail: sysoev.na@rea.ru
}

\begin{abstract}
This study presents a starting point in examining the issue of poverty in Russia as related to social strata. Since the Soviet Union's breakdown Russian Federation has undergone its own unique political, social, and economic transition process. So, to learn by experience all pros and cons of almost quarter of a century old Russian transition economy outcome very important is scholar's engaging in research to introduce stratums of the population in aspect of the economic inequalities. Mainly, the term «inequality» means that people have unequal access to scarce and valued resources in society which might be economic or political. Because, the stratification might refer to the hierarchical arrangement of people in a society both on economic and on sociologic points of view. Inequality and social classes became important analytical concepts for explaining and solving the problems of Russian society after the 1990s. In order to find the ways out from the existing problems first needed to define socioeconomic status and social class in Russia. But in the time of global economics new challenges appear and they set new standards for sustainable development and eradication of poverty.
\end{abstract}

\section{KEY WORDS}

Individuals, household, households, economically active population, economically inactive population, social status, transformation economy, poverty, social stratum, income inequalities.

Even Karl Marx (1887) in his famous fundamental work «Capital» declared that «My standpoint, from which the evolution of the economic formation of society is viewed as a process of natural history, can less than any other make the individual responsible for relations whose creature he socially remains, however much he may subjectively raise himself above them» [Marx K. (1995), p. 7]. Doubtless, it is very deep, mindful and pragmatic expression. Evidently, a society is a group of people involved in persistent social interaction. Within an analytic activity the definitions of social stratum could be made according to social, economic, political and cultural variables. That is why, even in socioeconomic research problems of social differentiations, for an obvious reason, are drawn in terms of basic sociological concepts: social role, status, and class. Inequality in Russia has stayed high throughout the transition period. Some experts consider that inequality is one of the incentives of competition. But anyways should not forget the government's role in the distribution of gross domestic product, ensuring equal competition and addressing social needs, which is substantial for the fight against poverty and sustainable development.

On earlier 90-s of the past century so called «young reformers» led by the Yegor Gaidar in Russia, which doubtless is an inseparable part of Europe (especially, because of European part of Russia to Ural Mountains), have undertook many serious and unpopular steps in order to transform its socialistic administrative-command economic system into a European-type market economy. Naturally, it was not easy after over 70 years of command socialism which provided central planning of the socialistic economy with its fully regulated inner market to create the common core of free market institutions, such as: private ownership protected by a commercial law, a corporate structure for industry, an independent financial system, and so forth. In that awful time Y.Gaidar and his team chose the controversial shock therapy reforms for fast overcome the collapse of economy which finally 
caused the dissolution of the Soviet Union. As it was fairly declared in Y.Gaidar's obituary notice which was published by "The Telegraph" on 16 Dec 2009 «Gaidar is most widely associated with the lifting of state price controls in January 1992, a move born out of the desperate need to save Russia from starvation and civil wan ${ }^{1}$. But should be remembered that mentioned decision to abolish price regulation by the state immediately resulted in a major increase in prices and in fact caused boost inflation to more than 1,000 per cent, which drove many state enterprises towards bankruptcy and wiped out the savings of millions of Russians. Some experts underlined that for the Russian population changing of existing political policy and associated with it economic system transition like in the other postcommunist countries which tried to put in place the institutions of a market capitalist economy was a rather painful process [Abalkin L.I. (2002); Rittenberg L. et al. (2012); ]. On the one hand, the state price control lifting in RF on earlier 1990s could be observed as a positive measure which opened chance for tight integration of the Russian economic system in a global free market. And, on the other, it was the fastest way to find outcome from the hard Russian economic stagnation because of consumer goods deficit. Thereby, the globalization of economic relationships in which RF has been practically incorporated and the systemic transformations which also have been started in Russia on 1992, like in the other postcommunist countries, are two interlacing processes and a mark of the turn of the century.

Even in his fundamental work "Inquiry into the nature and causes of the wealth of nations», known as well with short name of this scientific research as "The Wealth of Nations», and which have been published in 1776, Adam Smith set the paradigm about demand and supply as a basic invisible mechanism of the self-regulation of free market economy to define prices on goods and services. This paradigm has been accepted by the economic theory long ago and works till now. So, it is beyond dispute that in a market economy, prices adjust to changes in demand and supply [Sysoev N.A. et al. (2012); Rittenberg L. et al. (2012);]. Thereafter, individuals on the overall are main actors on consumer market because they make decision according to their demands and needs in case of free market. That is why individuals may make private provision for the risk to which they are subject, but the ability to do so is not always equally distributed among the population, and which depending upon various circumstances. Quite obvious is that free decisions could be made in case of equal abilities, including people's material ability. Thereby, the responsibility of the state is to take its place alongside the freedom of the individual and the benefits flowing from the market.

Nowadays there are exploring new approaches to consumption in the modern world. In this context the theory of perfect competition assumes homogeneity among the components of both the demand and supply sides of the market. But, due to opinion of some experts, diversity or heterogeneity is now the rule rather than the exception [Smith, W.R. (1995), p. 63]. But the consumer behaviour is in close relation with the material wellbeing of the country population. J. Stiglitz et al. (2010) stressed that «Material living standards are more closely associated with measures of net national income, real household income and consumption production can expand while income decreases or vice versa when account is taken of depreciation, income flows into and out of a country, and differences between the prices of output and the prices of consumer products» [Stiglitz J. et al. (2010), P. 13]. Thereby, several points can be made concerning the living standards regarding what is known about poverty in Russia.

Unfortunately, so far there are different points of views about the problematic aspects of development of the Russian Federation (hereinafter - RF) households after the Soviet Union breakdown and gaining of the country's real independence in 1992. However, there is a common vision about the issues concerning the direction of economic development of Russian households depends upon so many circumstances. Among the various should be considered their startup assets, stability of their material endowments, temps of economic development and economic situation in general in RF, which therefore could have great

\footnotetext{
1 "Yegor Gaidar". The Daily Telegraph. Published on 17 December 2009. URL:

http://www.telegraph.co.uk/news/obituaries/finance-obituaries/6827912/Yegor-Gaidar.html (Date of access 15 October 2016).
} 
influence on the social status of individuals and their households. Mainly, social stratification in any society defines through peoples competence and their wealth. For instance, according to K.Marx (1887), social class is determined by the ownership and control over of the means of production [Marx K. (1995)].

The socioeconomic status of individuals and, therefore, their households is one of those instruments which defines households' economic potential and activity. On the other hand, the socioeconomic status gives some notion about the economic stratification of civics classes within the society. No doubt, civics is a subject which touches every person's life in the society not only from the social-economic but also on the political points of view, because it deals with the value of being an active citizen in the community and common welfare. Therefore, it is quite natural, that through the full-scale study of civics, one can learn how governments work, how they came to be and how they affect the lives of their citizens. Nevertheless, should be understand that the nation was not built by government alone. The main national issue and the goal of any government according to the law in force is to set equal conditions for its citizens in order to promote the general welfare. Moreover, much of the strength of communities comes from individuals, families and private groups who work together to address issues and solve problems in communities. So, we suppose that by analyzing of the various components of the social status of the households might reach a deep understanding of how society works, or perhaps how it should work. In other words, socioeconomic status (hereinafter - SES) of individuals and households indicates one's access to collectively desired resources, be they material goods, money, power, friendship networks, healthcare, leisure time, or educational opportunities. So, in general, the resources might be either economic or political, such as education, jobs, health care, property and land ownership, housing, and ability to influence government policy. And it is access to such resources that enable individuals and/or groups to prosper in the social world.

\section{Social Stratification Levels}

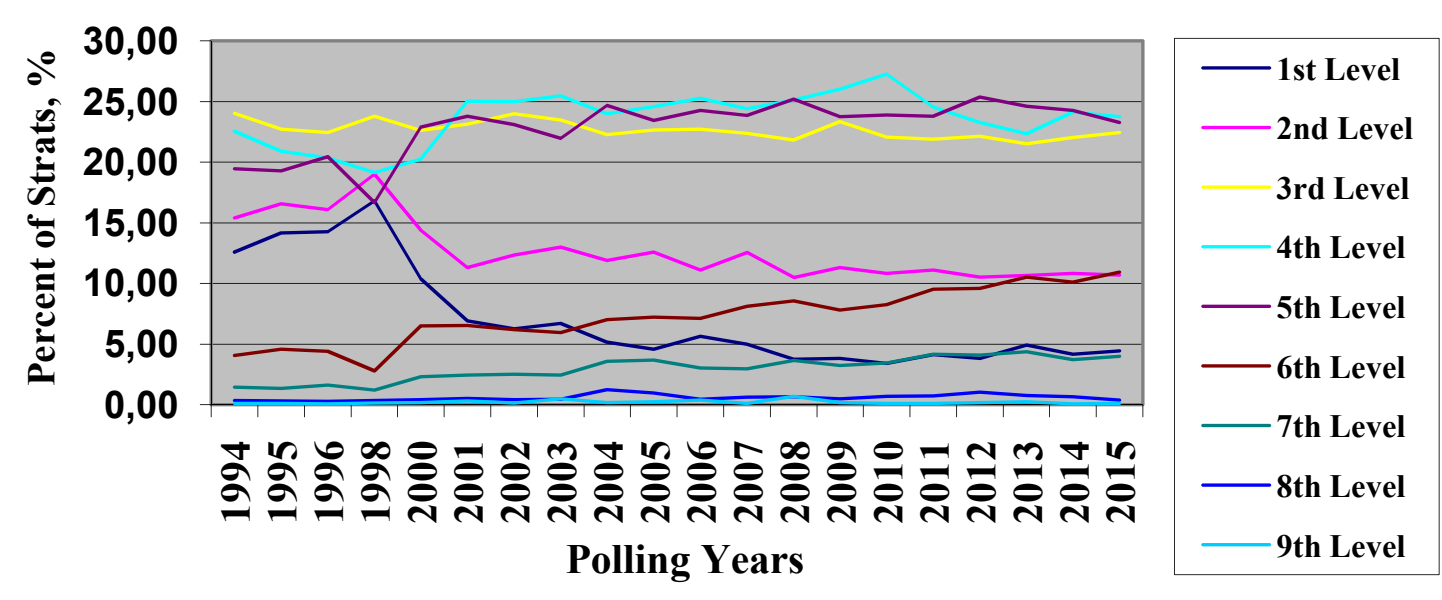

Figure 1 - Dynamic of Social Stratification by the RLMS-HSE Polling

Since 1994 have been conducting studies on the Russia Longitudinal Monitoring Survey (hereinafter - RLMS). The RLMS project is a series of nationally representative surveys designed to monitor the effects of Russian reforms on the health and economic welfare of households and individuals in the RF. The project initially run jointly by the Carolina Population Center at the University of North Carolina at Chapel Hill in cooperation with the Institute of Sociology of the Russian Academy of Sciences and the Russian statistical agency (hereinafter - Rosstat). And since 2008 the Russian Longitudinal Monitoring Survey (RLMS-HSE) is a nationally representative survey which is conducted by the National Research University Higher School of Economics (Moscow, Russia), ZAO 
«Demoscope» (Moscow, Russia) and the Institute of Sociology of the Russian Academy of Sciences together with Carolina Population Center, University of North Carolina at Chapel $\mathrm{Hill}^{2}$. As it was underlined by P. Kozyreva et al. (2015) the RLMS project initially has been created by the G-7 countries in 1992 in conjunction with the starting of the cardinal political and economic reforms in RF to obtain objective nationally representative data on the social, health and economic situation in Russia. The RLMS was created because the existing data, including a Family Budget Survey, were deemed unreliable, and adequate dietary, anthropometric and various other health-related behaviours were not measured in a nationally representative manner. [Kozyreva P. et al. (2015), P. 1]. Two years were missed, 1997 and 1999 due to funding problems of the project and failure of polling.

An analyzing information presented in this paper might reflects basic tendencies on social stratification that are formed in the RF in 1994-2015. According to the polling data individuals from 38 regions of the RF were questioned about their social status. The polled individuals were stratified in concordance with their self-identified social status. Have been used 9 grade scale: from the 1-st level which considered as poorest to the 9-th level - as richest (see figure 1). Presented stratification diagram is used to determine if polling population from various regions of RF is stratified according to a category related to the output and visually show manifested differences among them. According to this diagram if the data is stratified, the plotted points will exhibit unique patterns associated with the category. The variants for the 1-st level, which is the poorest population in percents from the total polled contingent since 1994 to 2015 has changed noticeably from 16,82 \% (highest on 1998 ) to $4,43 \%$ (but the lowest as $3,40 \%$ was mentioned on 2010). On the contrary, relative number of the 9-th level population, which was defined as richest, consequently at the same period was not changed remarkable. For instance, on 1994, 1995 and 2015 it was $-0,1 \%$ of the from the total polled group and the highest - 0,69 \% (on 2008) and the lowest - 0,08\% (was manifested on 2014). The summary number of the middle class polled group which consists of those who identified themselves among 4-th to 6-th social strata since 1994 to 2015 has been changed more significantly in total from the $38,68 \%$ (on 1998) to $59,41 \%$ (on 2010) and to 2015 has decline up to $57,94 \%$ but still stays great more higher then it was initially on $1994(46,06 \%)$ about 1,25 times. By analyzing this preliminary results might be supposed that there is tendency for enlarging middle class in RF during last years and good trend for its further development will be occurred.

Thus, it is obvious that measures of SES, and statistics based on them such as variances, are necessary to quantify if not understand the level of stratification or inequality in or between societies in various regions of the RF. However, Without sound measures of SES, it is impossible to capture and understand changes to the structure of a society. Nevertheless, without an understanding and sound measurement of SES, the relationship between other important social variables, such as race or sex, can be masked by the evident and often dominant relationship between outcomes and SES. Anyway, it should be remembered that some methods of population stratification can cause spurious associations if not adjusted properly.

\section{REFERENCES}

1. Abalkin L.I. (2002) Logika jekonomicheskogo rosta - M.: Institut jekonomiki RAN. - 228 s. (in Russ.).

2. Kozyreva P., Kosolapov M. and Popkin B.M. Data Resource Profile: The Russia Longitudinal Monitoring Survey - Higher School of Economics (RLMS-HSE) Phase II: Monitoring the Economic and Health Situation in Russia, 1994-2013. // International Journal of Epidemiology, 2015. - Vol. 1-7. - pp. 1-26. (in Russ.).

3. Marx K. (1995). Capital: A Critique of Political Economy. Volume I. Book One: The Process of Production of Capital / Translated: Samuel Moore and Edward Aveling, edited

\footnotetext{
2 "Russia Longitudinal Monitoring Survey of HSE". UNC Carolina Population Center. URL: http://www.cpc.unc.edu/projects/rlmshse/ (Date of access 15 October 2016).
} 
by Frederick Engels; / English edition first published in 1887; - Moscow: Progress Publishers, 1995. - 549 p.

4. URL: https://www.marxists.org/archive/marx/works/download/pdf/Capital-Volume-I.pdf (in Russ.).

5. Rittenberg L., Tregarthen T. Principles of Macroeconomics (v. 1.0). - Flat World Knowledge, Inc., 2012. - 909 p.

6. Smith, E.A., M.B. Mulder, S. Bowles, and K. Hill. (2011). "Wealth Inequality in Foraging, Horticultural, Pastoral, and Agricultural Populations" - Current Anthropology. - Vol. 52(4) - pp. $579-80$.

7. Smith, W.R. (1995). Product Differentiation and Market Segmentation As Alternative Marketing Strategies contemporary business scene. - Marketing management. - Vol. 4. - No. 3. - pp. 63-65.

8. Sysoev N.A., Orlov S.L. Segment produktov pitaniia na rossiiskom potrebitel'skom rynke: optimistichnyi vzgliad na slozhnye problemy / N.A. Sysoev, Orlov S.L.; Rossiiskii ekonomicheskii universitet im. G.V. Plekhanova. - Moskva, 2015. - 36 s. Dep.: FGBU RGB 27.10.2015 g., № 1168478 URL: http://dlib.rsl.ru/viewer/03001168478 (in Russ.).

9. Sysoev N.A. Strategicheskii i operatsionnyi marketing v obshchestvennom pitanii // Vestnik Rossiiskogo ekonomicheskogo universiteta im. G. V. Plekhanova. 2013. №3 (57). C. 102-106. (in Russ.).

10. Weber, M. (1922/1968). Economy and Society. Berkeley and Los Angeles: University of California Press.

11. Zacher H.F. Social Policy in a Free Market Economy // Zeitschrift für die gesamte Staatswissenschaft (ZgS) / Journal of Institutional and Theoretical Economies, 1982. Vol. 138. - pp. 345-350. 